\title{
Cross-boundary communities, an alternative vision for academic development
}

\author{
Chrissi Nerantzi, Peter Gossman \\ Manchester Metropolitan University, University of Worcester
}

\begin{abstract}
This opinion piece presents material derived from considered thoughts about the future of academic development and a phenomenographic study in which the collaborative open learning experience was explored within two cross-institutional academic development courses. The proposition for academic development shared in this article is based on some of the study's findings (those relating to cross-boundary community). These findings are synthesised with conceptual ideas to present an alternative approach to academic development. This approach connects academic staff, students and the public, diversifies the available offer and recasts it as dynamic practitioner-driven collaboration. Although it concerns academic development, the article is of interest to anyone involved in teaching and learning - and so, therefore, in exploring ways of engaging people with their development and to academics thinking about constructing open courses.
\end{abstract}

Keywords: Open education, academic development, phenomenography, open education community.

\section{Academic development in the UK}

Academic development in the UK is traditionally organised by a central academic development unit in a single institution for the staff of that institution, although there are many variations on this. The offer, for such units, commonly includes: cross-disciplinary, initial and in-service, formal and informal professional development related to learning and teaching for a range of staff who teach or support learning. It also covers: routes to professional recognition as well as postgraduate teaching qualification programmes (PGCerts); Masters and doctoral programmes; curriculum enhancement; pedagogical research and review activities in faculties and disciplines (Nerantzi, 2017a).

Over the last few years, some of the above provision has been made available to colleagues external to the institution, including institutional collaborative partners and others. Overall, academic development has a central function within UK higher education institutions (HEls) and academic development units (ADUs) play an increasingly strategic role in positively influencing teaching and learning across an institution (Baume and Baume, 2013; Bostock and Baume, 2016). These units offer teaching qualifications and professional recognition, which have been shown to shape teaching practices (Parsons et al., 2012; Botham, 2017). Furthermore, ADUs often also offer workshops and tailor-made interventions and work closely with colleagues in the disciplines and professional areas on curriculum design and review. Developers also promote and engage in scholarly activities to evaluate, enhance and transform learning and teaching and the student experience. Knapper (2016, p.106) notes of PGCerts that "these courses have exposed new academics to a much wider range 
of possible teaching and assessment approaches and promoted a more sophisticated understanding about how students learn and how best to teach". However, despite its effectiveness and successes, academic development (and its often traditional character) has been criticised for being behind the times (Donnelly, 2010; Littlejohn, 2002; Mainka, 2007). Stefani (2017) calls for academic development to break free from conventions and become transformative, to drive innovation in learning and teaching.

Researchers in this area (Crawford, 2009; European Commission, 2013; King, 2004) have called for more open, decentralised and collaborative academic development provision that stretches across institutions to maximise the opportunities presented for professional development by digital technology. Daniel, Kanwar and West (2007, p.1), in their keynote to the International Conference on Open and Online Learning, suggest that open learning "... means access to learning without barriers, access that is not closed. Open learning is an ideal, because there will always be some barriers to learning". Academic conferences that build cross-institutional community around them are examples of where this is achieved in short bursts. In some cases, the community may continue between annual conferences or be just an annual regrouping. Historical examples of wider-reaching collaboration show that this is not a new idea in academic development. The 1989 collaborative PGCert in central Scotland (Ellington and Baharuddin, 2000), with its focus on resources sharing, the London example in 1990-91 (Bostock and Baume, 2016) of a joint course - for academic staff in polytechnics and those in higher education (HE) - on teaching in HE, and Gibbs' (2012) vision for a national initiative in this field are all forward-thinking ideas and examples of cross-institutional collaboration, though they did not materialise or had a very short lifespan. Bostock and Baume (op.cit.) claim that perhaps the technology was not ready to help some of these ideas survive and spread. Since then, open and social practices supported by open and social media have created new opportunities in this area. Examples include 'Learning and Teaching in Higher Education' (\#LTHEchat - https://thechat.com/) and open professional development courses such as the 'Bring Your Own Devices for Learning' (BYOD4 - https://byod4learning.wordpress.com/) and the 'Teaching and Learning Conversations' webinars (TLC - https://tlcwebinars.wordpress.com/). A further example is the growth of open-access institutional research repositories (e.g. openDOAR http://v2.sherpa.ac.uk/opendoar/) and open-access journals. Digital practices, as noted by Beetham (2015), are often integrated into academic development provision and there are now diverse opportunities to set up community spaces using institutional, social and personal technologies. Community, as highlighted by Gunn (2011), can be created through collaborative approaches that are decentralised and not top-down mandates.

The literature related to this area often focuses on the formal nature of cross-institutional collaboration among HEls, omitting the valuable informal and open opportunities that collaborations can bring (British Council, 2015; European Commission, 2013 and 2015; HEFCE, 2011). Inanimorato dos Santos et al. (2016) advocate inter-institutional collaborations that are informal and practitioner-led, as they offer opportunities to share practice and resources, empower individuals in a dynamic way and act without the need for any institution to have a formalised partnership with another. A few such informal cross-institutional groupings of practitioners have started seizing opportunities and currently offer open and cross-institutional professional development initiatives - such as the Creativity for Learning in 
Higher Education and the Flexible, Distance and Online Learning course (Nerantzi, 2017a) that are based on informal collaborations.

\section{Exploring the collaborative open learning experience}

Two specific open, cross-institutional academic development courses in 2014 and 2015 (Nerantzi, 2017a) explored the collaborative open-learning experience of academics and non-academic professionals in HE (who teach or support learning). A phenomenographic approach was used to study the authentic lived experience of participants and the related qualitatively different variations in it (Marton, 1981). Data from two courses were collected through twenty-two individual semi-structured interviews, by means of a collective casestudy approach (Stake, 1995). The open courses in this study were the 'Flexible, Distance and Online' (FDOL - https://fdol.wordpress.com/) and 'Creativity for Learning in Higher Education' (\#creativeHE - community space at https://plus.google.com/communities/110898703741307769041).Both were informal crossinstitutional collaborations and linked to at least one formal professional development programme - such as a PGCert or MA in Learning and Teaching in Higher Education within an institution. They both had different collaborative learning features, were organised by facilitators situated in different institutions and were open to staff, students and the public (Nerantzi, 2017a).

Eleven categories of description and their limited number of qualitatively-different variations (Appendix 1) emerged through analysing the data that describe aspects of the learners' experiences, including course features and boundary-crossing that influenced and shaped this, including collaborative open learning. The outcome space depicts the logical relationships among the categories of description (Appendix 2). These findings were used to construct a cross-boundary, collaborative open-learning framework (Appendix 3). It is proposed that the framework could be used and adapted by those considering the development and implementation of cross-institutional academic development - or, indeed, other provision.

Phenomenography, as a methodology, captures the voices and perspectives of experience as lived and described by all study participants collectively through categories of description and their qualitatively-different variations (Marton, 1981). This means that the whole spectrum of responses is brought together and then synthesised through analysis. This article explores one specific category of description - 'course as community' (Nerantzi, 2017a) - and discusses the opportunities this presents for an alternative community-based approach to academic development that could work in conjunction with other established approaches. The authors propose this to widen the current academic-development offer and attract, as this research showed, academics to whom such an approach could be attractive.

\section{Course as community'}

Community featured in the findings at two levels, in relation to the individual learner and to a sense of belonging to a group. This generated community feelings seen as valuable for their learning on- and offline. Some study participants in 'Course as community' expressed interest in a continuation of the community beyond the course. The eleven categories of description emerging from the study through a phenomenographic analysis provide insight into how collaborative open learning was experienced in two open, cross-institutional academic development courses (Appendix 1). The category of description "cross-boundary 
learning through time, places and space' (Nerantzi, 2017b) suggests that the adopted socialmedia 'patchwork strategy' (Wenger et al., 2009, p.127) was effective in fostering opportunities for cross-boundary collaborative open learning, online, offline and on the go for the course participants, and therefore contributed to the creation of the community. The offline dimension sparked local satellite communities with one participant taking the community concept back to her institution, where she was confident that her local support network would be sufficient for her needs without further online contact with anyone from the course. An illustration of the ripple effect that the open community created resulting in extended engagement beyond the boundaries of the open courses.

The related findings also suggest that, whilst the two courses in the study had a predefined duration, some participants experienced collaborative open learning as a continuum stretching beyond the course conclusion - because of the cross-boundary nature of community, as depicted in the outcome space within Area A (Appendix 2). Participant C4 says:

"The fact that some of that group I know will carry it on, is great. I found myself thinking this is no time at all, I've only just got into it and it's finishing. Okay, now that's easy to see from this perspective, if at the beginning you said this course is going to be twenty weeks I would have gone, oh my god I can't manage that commitment. So somehow I think the magic word would be extension ability would be the thing that is important, if it looks too big from the outset then that gets in the way and my disappointment was just that it was ending, but I'm not really disappointed because I'm not letting it end because that little group will keep talking."

This perspective shows that participants not only experienced collaborative open learning as a community, but also saw the course itself as an opportunity offering access to a professional community stretching beyond the conclusion of the course. This suggests that the courses, for such participants, were valuable both for the continuing development of their teaching practice and for creating a sense of community and belonging.

The work of Parsons et al. (2012) illustrates that community can be built through long crossdisciplinary academic development programmes that operate for many years within institutions, such as PGCerts. The findings of this study indicate that fostering extended community beyond the boundaries of a specific programme can create continuous opportunities for professional development for staff. Indeed, participants in the study expressed a desire to be part of a wider community, not only cross-disciplinary, but also cross-institutionally and cross-boundary. The cross-boundary nature of this community appears to have acted as a strong motivator for participant engagement. Interaction with other course participants helped them to get to know - and develop professional relationships with - a diverse set of individuals from different institutions, cultures, countries and sectors; that they were able to do this appears to have also strengthened their commitment to the course. This study therefore extends Crawford's (2009) work related to the engagement, after their completion of an institutional PGCert, of academic staff with external disciplinary communities and networks; it also provides evidence of such activities in cross-institutional, cross-disciplinary and cross-boundary settings for the continuing development of teaching. 
The two cross-institutional academic development courses designed by the course organisers had features in common with the community-building academic development model as defined by Popovic and Plank (2016). According to these authors, a 'communitybuilding' model enables academic staff to come together informally to share ideas and support each other beyond the disciplinary or hierarchical boundaries within an institution. They acknowledge that such communities can be extended beyond an institution. The model adopted in the two courses had a deliberately cross-institutional dimension; they brought formal and informal learning and development together; and they were open to all academic staff, students and the public. The practices reflect the idea of cross-boundary communities, as articulated by Perryman and Coughlan $(2013,2014)$ from their research into informal communities that connect HE and the public. Their work illustrates the opportunities for and the value of cross-boundary communities - equally relevant to the bringing together of formal and informal learning in open cross-institutional settings.

\section{Towards an alternative approach}

During this research, evidence was gathered in relation to the attractiveness of such practitioner-led collaborations in the area of open cross-institutional academic development (Nerantzi, 2017a; Nerantzi, 2017b). The two courses in this study brought together a diverse range of open learners including academic developers, learning technologists, academic staff and students from different cultures, and further individuals with different roles within and beyond $\mathrm{HE}$, thus creating diverse development opportunities.

We propose that such collaborative and open approaches to academic development involving cross-institutional collaborations - be used as a strategy to build extended communities for continuously engaging academic staff in professional development. Such an approach may also help remove some of the negative perception that sometimes exists among academic staff towards academic development, especially when it is perceived as management-directed (Crawford, 2009; Gibbs, 2013; Di Napoli, 2014). Research has shown that collaborative and partnership approaches to academic development are perceived by academic developers and academic staff as much more effective in terms of academic staff engagement (Stefani, 2003; Wareing, 2004).

This alternative approach of academic development may contribute to developing trust and portray a more inclusive and collegial picture of academic development based on open collaboration and positioned within practice and the academic community instead of being an add-on; a place of belonging, instead of a destination. The findings of this phenomenographic study point in this direction. The extract below from a study participant illustrates this.

"The course has been a crucial eye-opener for me [...] it relates to the way in which, it's being run across multiple institutions. Because, for me, there's a big risk with open learning, that if it comes badged by a single institution, that educational developers, academic developers are automatically inclined to be resistant to advocating that for colleagues in their own institution. For fear of it actually, either undermining or, worse still making them redundant. So, the differences with this course is that there's been an attempt to diffuse that problem, by having it facilitated by colleagues in more than one institution, and then when you look at the PBL facilitators furthermore, even more institutions again, so leaving it open for the 
instruction of the course, the delivery of it to be facilitated by multiple institutions effectively. And I think that erodes that problem of feeling as though it belongs to another competitor. And that we would be offering it. So there's something really nice about that. But it's more than open learning, it's about open practice as well. It's about making sure that the model of the course can accommodate, and invites facilitation from others in other institutions."

This participant confirms that such organised cross-institutional collaborations - in the area of academic development co-facilitated by a group of distributed facilitators - provide a model for extending opportunities for academic development that is decentralised and distributed, based on open collaboration and, as the evidence suggests, perceived as more attractive to academic staff. Facilitators in the two courses of the study were from different backgrounds and different institutions and organisations. They were learning alongside course participants, as co-learners. This model of learning, in which power-relationships were flattened/horizontal, enabled wider learning partnerships to emerge and develop among students and academic staff also. The cross-boundary nature of the courses further amplified related opportunities, as likewise observed by Engeström, Engeström and Kärkkäinen (1995). This provides evidence that the non-hierarchical characteristics of a community offer the space to enable such boundary-crossing partnerships.

The findings illustrate that informal academic development community-building models (Popovic and Plank, 2016) can play a key role in proactively and continuously engaging academic staff. The study offers new evidence that, as Crawford's (2009) work showed, academic staff engage in external communities and networks to develop their teaching. The findings also suggest that open collaborative and cross-institutional approaches should be considered by academic developers (potentially all academics) and their institutions, as they are wider-reaching, enable academic staff (and students) to experience digital, collaborative and open learning and allow them to be part of vibrant and diverse professional development communities. Such collaborative approaches to academic development can open new pathways - not exclusively for engagement in informal professional development, for they can be equally valuable for professional recognition and credentialing (and therefore linking to academic programmes and other existing provision within and beyond a specific institution).

The proposed idea for an alternative academic development model is based on crossboundary communities. This way of conducting academic development presents an opportunity to develop a distributed and collaborative approach for ADUs that stretches beyond institutional boundaries and creates opportunities to work more closely and in partnership with other units and practitioners in other institutions and organisations: academic developers, learning technologists, academics, students and other professionals from HE and other sectors. The foundation of such an approach consists of cross-boundary communities providing continuing opportunities to engage online, offline and across physical and digital boundaries (Nerantzi, 2017a). Through this community, further academic development activities can be offered by individuals and groups of practitioners, or crossinstitutionally. They can include focused conversations, courses, modules and programmes, as well as workshops and one-to-one support. It is not suggested that a community-based model will work for all academics. To the contrary, and as Nerantzi (2017a) shows, there will 
be academic staff who are selective in their approach to professional development for whom 'community' may play a lesser - or no - role as a motivator for engagement.

However, considering the current development needs of academic staff and the increased emphasis and conflicting pressures on academic staff to keep up to date and continuously raise the quality of their teaching and concurrently produce research outputs, a crossboundary community-based academic development model could provide an alternative, the means of engaging academic staff proactively in formal and informal professional development. It can also enrich and diversify existing academic development provision, which often still has an internal institutional focus. Evidence from Nerantzi (2017a) shows that this way of developing - practice-based, interest- and needs-driven - motivates and can empower academic staff.

If academic development is going to thrive in the years to come, it needs to re-invent itself so that it is of recognisable and immediate value to the academic community it serves and to communities more widely; and so that it becomes transformative (Stefani, 2017). Weller (2014) noted that learning and teaching is becoming more open and collaborative and there is some evidence that this has started happening in the area of academic development (Nerantzi, 2015). Rennie and Reynolds (2014) argued that decentralisation and collaboration could lead to open models and this study offers some evidence of this. However, traditional university cultures, as noted by Bayne and Ross (2014), may present challenges to such implementations. Furthermore, the drive, in England at least, to achieve teaching excellence based on highly-competitive models (BIS, 2016a; BIS, 2016b; Nerantzi, 2017b) also presents a barrier to wider collaboration among HEls that may lead to reduced collaboration among institutions and hinder the opportunities for and benefits of implementation of community-based professional development models.

It needs to be acknowledged that practitioner-driven collaborative, cross-institutional and cross-boundary community approaches to academic development, supported by technology and based on the values of open education, can empower academic staff to engage in academic development through community engagement - a safe space for social learning. The modelling of innovative and more novel practices in these settings is important, enabling academic staff first to experience and consider them before applying them to their own practice (Beetham, 2015).

\section{Possible Wider Implications}

In a thought piece in 2015, we suggested that the world might move to a place where academic development and $\mathrm{HE}$, as a function, were no longer required, as people are all "expert, emotionally intelligent, self-regulated learners" (Nerantzi and Gossman, 2015, p.22). A utopian future: a learning society of dynamic networks and communities, proactive engagement, horizontal structures; choice, co-operation and empowerment.

What seems to be required, as suggested by this research, are prepared and motivated individuals who will engage with open courses, with their content and with the other participants. Those who do - and perhaps this is a truism - find the experience challenging and rewarding in equal measure. Arguably, courses that contain such individuals create their own community. In the context of learning solely online, Nolan and Kellar (2018) note that greater 'community' enhances the online education experience and, broadly, that student-to- 
student task-related interactions foster such a collaborative group. For this to happen, however, students probably also need to work alongside facilitators who are 'present, guiding, open, honest and human' (Outzs, 2006, p.292).

What is suggested above accords with Education 3.0, "where education is socially constructed and contextually reinvented", as outlined by John Moravec (2008), and is summarised by Gerstein (n.d.) as "a connectivist, heutagogical approach to teaching and learning. The teachers, learners, networks, connections, media, resources, tools create a unique entity that has the potential to meet individual learners', educators', and even societal needs."

\section{Conclusion}

This research suggests that open, cross-institutional collaborative approaches, based on cross-boundary communities, should be considered by institutions and practitioners as alternative academic development. These approaches extend the reach of academic development, enable staff to experience digital and open learning and allow them to feel part of a vibrant and diverse professional development community that acts as a motivator for further extended engagement. Such developments might bring informal, formal and open learning and development together and provide new pathways towards professional recognition and credentialing.

The concluding fascinating fiction article in 'Zombies in the Academy: Living Death in Higher Education' (Whelan et al., 2013) comments: "After the outbreak of Viral-Z, knowledge proved too precious a commodity to be located in any one institution" (p.331). Considering the development of academic staff and the increased emphasis on, and need for, keeping up to date and enhancing teaching practice, a community-based model of open, cross-institutional courses can provide alternative ways to engage academic staff in professional development, as well as enable academic developers to learn from and with each other. It can turn academic development from an internally-focused to a cross-institutional and cross-boundary-focused provision that reaches academic staff and engages them proactively in academic development.

\section{Acknowledgements}

We would like to thank Margy MacMillan for reading the first draft of this paper as well as the reviewers for their valuable suggestions.

\section{Reference list}

Bayne, S. and Ross, J. (2014) The pedagogy of the massive open online course: the UK view. York: Higher Education Academy. Available at:

https://www.heacademy.ac.uk/resources/detail/elt/the pedagogy of the MOOC UK view (Accessed: 17 February 2018).

Beetham, H. (2015) Developing digital know-how: building digital talent: Key issues in framing the digital capabilities of staff in UK HE and FE. Bristol: Jisc. Available at: 
https://digitalcapability.jiscinvolve.org/wp/files/2015/08/5.-Report.pdf (Accessed: 11 February 2018).

BIS (2016a) Success as a knowledge economy: Teaching Excellence, Social Mobility and Student Choice, Department for Business, Innovation \& Skills. London: BIS. Available at: https://www.gov.uk/government/uploads/system/uploads/attachment data/file/523396/bis16-265-success-as-a-knowledge-economy.pdf (Accessed: 20 February 2018).

BIS (2016b) Teaching excellence framework: Year two specification. Department for business, innovation \& skills. London: BIS. Available at:

https://www.gov.uk/government/uploads/system/uploads/attachment data/file/556355/TEF Year 2 specification.pdf (Accessed 20 February 2018.

Bostock, S. and Baume, D. (2016) 'Professions and professionalism in teaching and development.' In: Baume, D. and Popovic, S. (eds.) Advancing practice in academic development. Oxon: Routledge, 32-51. ISBN 1138854719.

Botham, K.A. (2017) 'The perceived impact on academics' teaching practice of engaging with a higher education institution's CPD scheme.' Innovations in Education and Teaching International, 55(2), 164-175. Available at: https://doi.org/10.1080/14703297.2017.1371056 (Accessed 29 October 2018).

Boud, D. (1995) 'Meeting the challenges.' In: Brew, A. (ed.) Directions in staff development. Buckingham: The Society for Research into Higher Education and Open University Press, 203-223. ISBN 033519270X.

British Council (2015) Connecting universities: Future models of higher education. Analysing innovative models for Afghanistan, Bangladesh, India, Nepal, Pakistan and Sri Lanka. An economist intelligence unit report produced for the British Council, January 2015. Available at:

http://www.britishcouncil.org/sites/britishcouncil.uk2/files/new_university_models_jan2015_pr int.pdf (Accessed 11 February 2018).

Crawford, K. (2009) Continuing professional development in higher education: Voices from below. Lincoln: University of Lincoln. Available at:

http://eprints.lincoln.ac.uk/2146/1/Crawford-Ed\%28D\%29Thesis-CPDinHE-

FINAL\%28Sept09\%29.pdf (Accessed 11 February 2018).

Cronin, C. (2017). 'Openness and Praxis: Exploring the Use of Open Educational Practices in Higher Education.' International Review of Research in Open and Distributed Learning, 18(5). Available at: http://www.irrodl.org/index.php/irrodl/article/view/3096/4301 (Accessed 29 October 2018)

Daniel, J., Kanwar, A. and West, P. (2007, June) 'Open educational resources: Help or hindrance to open learning?' Opening Address presented at the International Conference on Open and Online Learning, Penang. Available at http://oasis.col.org/bitstream/handle/11599/1496/2007 DanielKanwarWest OERHelporHindr ance Transcript.pdf? sequence $=1$ \&isAllowed $=y$ (Accessed 29 October 2018). 
Donnelly, R. (2010) 'Harmonizing technology with interaction in blended problem-based learning. Computers \& Education, 54(2), 350-359. Available at:

https://doi.org/10.1016/j.compedu.2009.08.012 (Accessed 29 October 2018).

Di Napoli, R. (2014) 'Value gaming and political ontology: between resistance and compliance in academic development.' International journal for academic development, 19(1), 4-11. Available at: https://doi.org/10.1080/1360144X.2013.848358 (Accessed 29 October 2018).

Ellington, H. and Baharuddin, A. (2000). A practical guide to instructional design. Peneribit: UTM. ISBN 9835201919.

Engeström, Y., Engeström, R. and Kärkkäinen, M. (1995) 'Polycontextuality and boundary crossing in expert cognition: Learning and problem solving in complex work activities.' Learning and Instruction, 5(4), 319-336. Available at: https://doi.org/10.1016/09594752(95)00021-6 (Accessed 29 October 2018).

European Commission (2013) High level group on the modernisation of higher education. Report to the European commission on improving the quality of teaching and learning in Europe's higher education institutions. Available at: http://ec.europa.eu/education/highereducation/doc/modernisation_en.pdf (Accessed 11 February 2018).

European Commission (2015) Draft 2015 joint report of the council and the commission on the implementation of the strategic framework for European cooperation in education and training (ET2020). New priorities for European cooperation in education and training, Brussels: European Commission. Available at: http://ec.europa.eu/education/documents/et2020-draft-joint-report-408-2015 en.pdf (Accessed 11 February 2018).

Gerstein, J. (n.d.) User Generated Education - Education as it should be - passion-based. Education 3.0 and the Pedagogy. (Andragogy, Heutagogy) of Mobile Learning. Available at: https://usergeneratededucation.wordpress.com/2013/05/13/education-3-0-and-thepedagogy-andragogy-heutagogy-of-mobile-learning/ (Accessed 26 February 2018).

Gibbs, G. (2012) Implications of 'dimensions of quality' in a market environment. York: The Higher Education Academy. Available at:

http://www.heacademy.ac.uk/assets/documents/evidence_informed_practice/HEA_Dimensio ns_of_Quality_2.pdf (Accessed 11 February 2018).

Gibbs, G. (2013) 'Reflections on the changing nature of educational development.' International journal for academic development, 18(1), Mar. 2013, pp.4-14. Available at: https://doi.org/10.1080/1360144X.2013.751691 (Accessed 29 October 2018).

Gunn, C. (2011) 'Innovation and change.' In: Stefani, L. (ed.) Evaluating the effectiveness of academic development. Principles and practice. Oxon: Routledge, 73-86. ISBN 9780415872065.

HEFCE (2011) Collaborate to compete - Seizing the opportunity of online learning for UK higher education. Available at: http://bit.ly/gZloBB (Accessed 11 February 2018). 
Inamorato dos Santos, A., Punie, Y. and Castaño-Muñoz, J. (2016) Opening up Education: A support framework for higher education institutions. JRC Science for Policy Report, EUR 27938 EN: doi: 10.2791/293408. Available at: http://ec.europa.eu//rc/en/publication/eurscientific-and-technical-research-reports/opening-education-support-framework-highereducation-institutions (Accessed 12 February 2018).

King, H. (2004) 'Continuing professional development in higher education: What do academics do?' Educational developments, 5(4), 1-5. Available at:

http://www.seda.ac.uk/resources/files/publications_25_Educational\%20Dev\%205.4.pdf (Accessed 12 February 2018).

Knapper, C. (2016) ‘Does educational development matter?' International Journal for Academic Development, 21(2), 105-115, DOI: 10.1080/1360144X.2016.1170098 Available at: https://doi.org/10.1080/1360144X.2016.1170098 (Accessed 29 October 2018).

Littlejohn, A. (2002) 'Improving continuing professional development in the use of ICT.' Journal of Computer Assisted Learning, 18(2), 166-174. Available at: https://doi.org/10.1046/j.0266-4909.2001.00224.x (Accessed 29 October 2018).

Mainka, C. (2007) 'Putting staff first in staff development for effective use of technology in teaching.' British journal of educational technology, 38(1), 158-160. Available at: https://doi.org/10.1111/j.1467-8535.2006.00624.x (Accessed 29 October 2018).

Marton, F. (1981) 'Phenomenography - describing conceptions of the world around us.' Instructional Science, 10, 177-200. Available at: https://doi.org/10.1007/BF00132516 (Accessed 29 October 2018).

Moravec, J. (2008) Toward Society 3.0: A New Paradigm for 21st century education 1. Toward Society 3.0: A New Paradigm for 21st century education. Available at: https://www.slideshare.net/moravec/toward-society-30-a-new-paradigm-for-21st-centuryeducation-presentation (Accessed 26 February 2018).

Nerantzi, C. (2017a) Towards a framework for cross-boundary collaborative open learning for cross-institutional academic development. (PhD thesis) Edinburgh: Edinburgh Napier University. Available at: https://www.napier.ac.uk/ /media/worktribe/output1025583/towards-a-framework-for-cross-boundary-collaborative-open-learning-for.pdf (Accessed 11 February 2018).

Nerantzi, C. (2017b) 'Quality teaching through openness and collaboration - an alternative to the TEF?' Compass: Journal of Learning and Teaching, 10(2). Available at: https://journals.gre.ac.uk/index.php/compass/article/view/485 (Accessed 29 October 2018).

Nerantzi, C. (2015) 'Who says academics don't do CPD? Connecting practitioners and developing together through distributed cross-institutional collaborative CPD in the open.' In: Rennie, F. (ed.) The distributed university, 3(1), 98-108. Available at https://doi.org/10.14297/ipaap.v3i1.136 (Accessed 29 October 2018).

Nerantzi, C. and Gossman, P. (2015) 'Academic Development, a developers' society.' In: Educational Development Magazine, 16(4), 21-22. Available at:

https://www.seda.ac.uk/past-issues/16.4 (Accessed 29 October 2018). 
Nerantzi, C., Wilson, J., Munro, N., Lace-Costigan, G. and Currie N. (2014) 'Warning! Modelling effective mobile learning is infectious, an example from higher education,' UCISA best practice guide using mobile technologies for learning, teaching and assessment, Available at:

http://www.ucisa.ac.uk/ /media/Files/publications/case_studies/ASG_Effective_Use_Mobile \%20Learning (Accessed 23 February 2018).

Nolan, M. and Kellar, B. (2018) Online learning community: Friend or faux? White Paper. Corvallis, OR: Oregon State University Ecampus Research Unit. Available at: http://ecampus.oregonstate.edu/research/wp-content/uploads/Nolan-Kellar-final.pdf (Accessed 23 February 2018).

Ouzts, K. (2016) 'Sense of community in online courses.' The Quarterly Review of Distance Education, 7(3), 285-296. Available at: https://www.learntechlib.org/p/106764/ (Accessed 29 October 2018).

Perryman, L.-A. and Coughlan, T. (2013) 'The realities of reaching out: enacting the publicfacing open scholar role with existing online communities.' Journal of Interactive Media in Education, 3(21). Available at http://oro.open.ac.uk/39100/ (Accessed 10 February 2018).

Perryman, L.-A. and Coughlan, T. (2014) 'When two worlds don't collide: can social curation address the marginalisation of open educational practices and resources from outside academia?' Journal of Interactive Media in Education, 2(3). Available at: http://oro.open.ac.uk/41629/1/344-2731-1-PB.pdf (Accessed 10 February 2018.

Parsons, D., Hill, I., Holland J. and Willis, D. (2012) Impact of teaching development programmes in higher education. York: The Higher Education Academy. Available at: https://www.heacademy.ac.uk/system/files/resources/hea_impact_teaching_development_pr og.pdf (Accessed 18 February 2018).

Popovic, C. and Plank, K. (2016) 'Managing and leading change. Models and practices.' In: Baume, D. and Popovic, S. (eds.) Advancing practice in academic development. Oxon: Routledge, 207-224. ISBN 1138854719.

Rennie, F. and Reynolds, P. (2014) 'Two models for sharing digital open educational resources.' Journal of Perspectives in Applied Academic Practice, 2(2), 17-23. Available at: https://doi.org/10.14297/jpaap.v2i2.108 (Accessed 29 October 2018).

Stefani, L. (2017) 'Realizing the potential for creativity in teaching and learning.' In: Watts, L.S. and Blessinger, P. (eds.) Creative Learning in higher education. International perspectives and approaches. Oxon: Routledge, 196-209. ISBN 9781138962354.

Stefani, L. (2003) 'What is staff and educational development?' In: Kahn, P. and Baume, D. (eds.) A Guide to Staff \& Educational Development. Oxon: Routledge, 9-23. ISBN 0749438819.

Wareing, S. (2004) 'It ain't what you say, it's the way that you say it: an analysis of the language of educational development.' Educational Developments 5(2), 9-11. Available at: https://repository.royalholloway.ac.uk/items/ce1d0f02-d09d-a48f-aa51-4f1251f19f57/7/ (Accessed 29 October 2018). 
Weller, M. (2014) The battle for open. How openness won and why it doesn't feel like victory. London: Ubiquity Press. ISBN 9781909188334. 
Appendix 1: Categories of description

\begin{tabular}{|c|c|c|c|}
\hline $\begin{array}{l}\text { Pool of } \\
\text { Meanings }\end{array}$ & $\begin{array}{l}\text { Categories of } \\
\text { description }\end{array}$ & Variations & $\begin{array}{l}\text { Codes } \\
\text { used in } \\
\text { the } \\
\text { outcome } \\
\text { space }\end{array}$ \\
\hline \multirow[t]{4}{*}{$\begin{array}{l}\text { Pool } 1 \\
\text { (Course) }\end{array}$} & $\begin{array}{l}\text { Open learning as } \\
\text { course organisation }\end{array}$ & $\begin{array}{l}\text { Causing initial disorientation } \\
\text { Aiding participation }\end{array}$ & C1.1 \\
\hline & $\begin{array}{l}\text { Open learning as an } \\
\text { activity-based } \\
\text { experience }\end{array}$ & $\begin{array}{l}\text { Limiting engagement } \\
\text { Fostering engagement }\end{array}$ & C1.2 \\
\hline & $\begin{array}{l}\text { Open learning as a } \\
\text { facilitated experience }\end{array}$ & $\begin{array}{l}\text { Lacking direction and instruction } \\
\text { Directive and controlling } \\
\text { Facilitative and supportive }\end{array}$ & C1.3 \\
\hline & $\begin{array}{l}\text { Open learning as } \\
\text { designed for } \\
\text { collaboration }\end{array}$ & $\begin{array}{l}\text { Constraining } \\
\text { Enabling } \\
\text { Empowering }\end{array}$ & C1.4 \\
\hline \multirow[t]{4}{*}{$\begin{array}{l}\text { Pool } 2 \\
\text { (Boundary } \\
\text { crossing) }\end{array}$} & $\begin{array}{l}\text { Cross-boundary } \\
\text { learning through } \\
\text { modes of participation }\end{array}$ & $\begin{array}{l}\text { As a valued informal learning } \\
\text { experience } \\
\text { As a valued mixed-mode learning } \\
\text { experience } \\
\text { As a valued opportunity for } \\
\text { recognition }\end{array}$ & C2.1 \\
\hline & $\begin{array}{l}\text { Cross-boundary } \\
\text { learning through time, } \\
\text { places and space }\end{array}$ & $\begin{array}{l}\text { As a disconnected experience } \\
\text { As a continuum }\end{array}$ & C2.2 \\
\hline & $\begin{array}{l}\text { Cross-boundary } \\
\text { learning through } \\
\text { culture and language }\end{array}$ & $\begin{array}{l}\text { As a barrier } \\
\text { As an enrichment }\end{array}$ & C2.3 \\
\hline & $\begin{array}{l}\text { Cross-boundary } \\
\text { learning through } \\
\text { diverse professional } \\
\text { contexts }\end{array}$ & $\begin{array}{l}\text { As initial discomfort } \\
\text { As a catalyst }\end{array}$ & C2.4 \\
\hline \multirow[t]{3}{*}{$\begin{array}{l}\text { Pool } 3 \\
\text { (Collaboration) }\end{array}$} & $\begin{array}{l}\text { Collaboration as } \\
\text { engagement in } \\
\text { learning }\end{array}$ & $\begin{array}{l}\text { Selective } \\
\text { Immersive }\end{array}$ & C3.1 \\
\hline & $\begin{array}{l}\text { Collaboration as a } \\
\text { means to shared } \\
\text { product creation }\end{array}$ & $\begin{array}{l}\text { Product-process tension } \\
\text { Fulfilling }\end{array}$ & C3.2 \\
\hline & $\begin{array}{l}\text { Collaboration as } \\
\text { relationship building }\end{array}$ & $\begin{array}{l}\text { Questioning the behaviour of others } \\
\text { Valuing the presence of others }\end{array}$ & C3.3 \\
\hline
\end{tabular}




\section{Appendix 2: The outcome space}

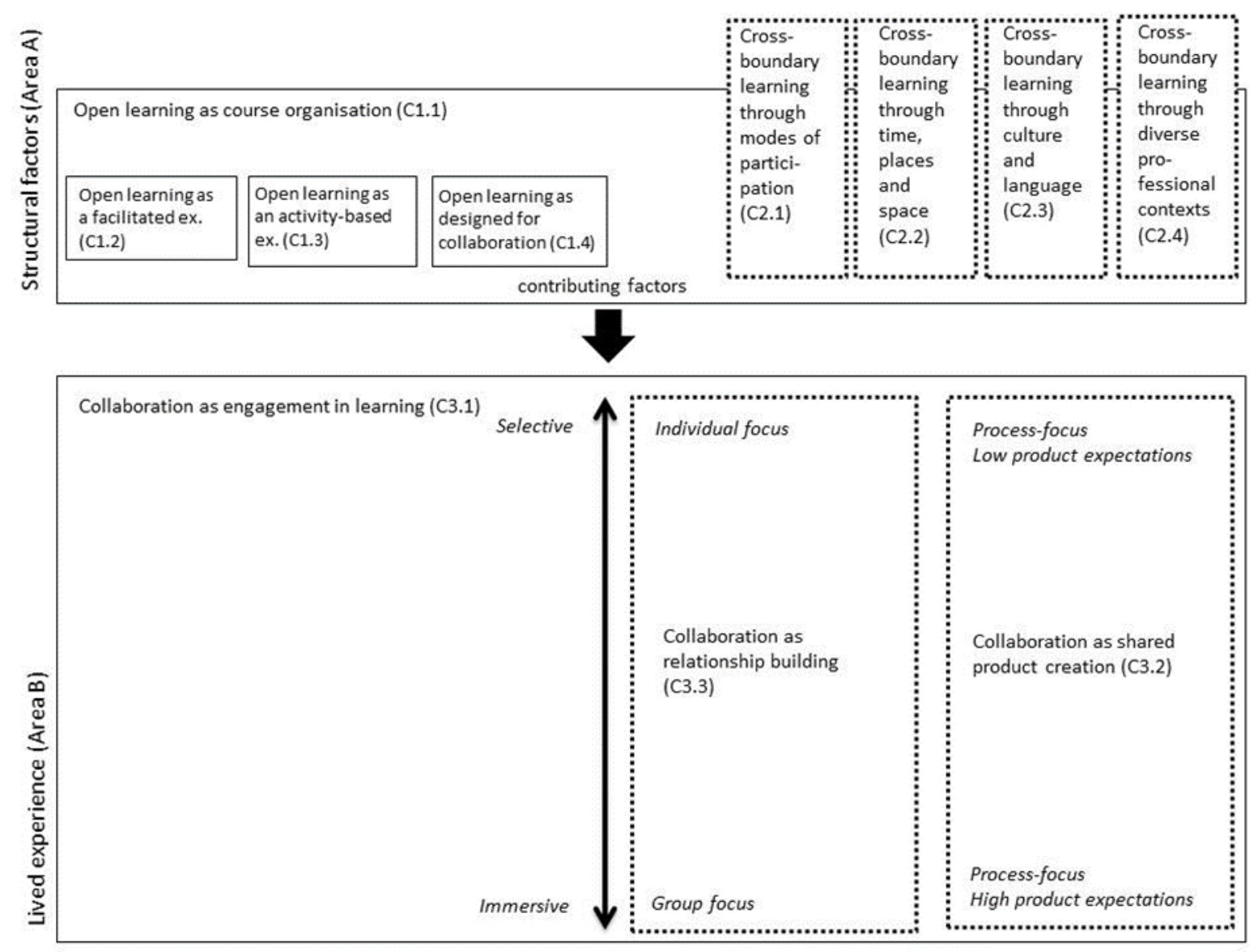




\section{Appendix 3: The cross-boundary collaborative open learning framework}

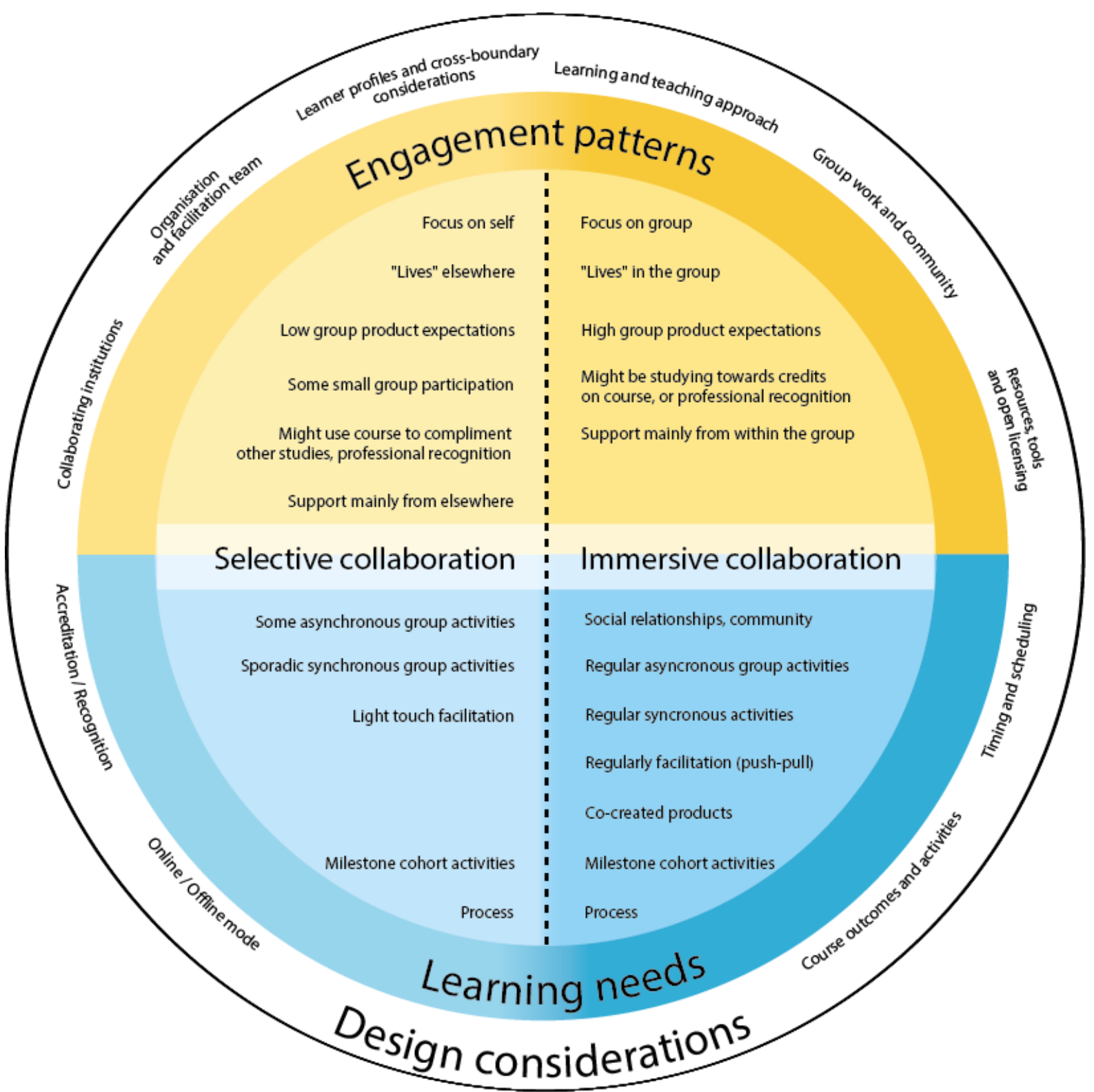

